\title{
COMPARISON OF INVADED AND NON-INVADED SITES: A CASE STUDY OF ROUGH COCKLEBUR (XANTHIUM STRUMARIUM L.) AN ALIEN INVASIVE SPECIES
}

\author{
UlLAH, R. - KHAN, N. ${ }^{*}$ - RAHMAN, A. \\ Department of Botany, University of Malakand, Chakdara Dir Lower 18800, Khyber \\ Pakhtunkhwa, Pakistan \\ *Corresponding author \\ e-mail:nasrullah.uom@gmail.com \\ (Received $30^{\text {th }}$ Nov 2020; accepted $27^{\text {th }}$ Jan 2021)
}

\begin{abstract}
The present research focuses on the comparison of soil physiochemical properties, nutrients, and vegetation that are important factors influenced by the invasive species in the new environment. We compared the abiotic and biotic factors between Xanthium strumarium invaded sites and adjacent non-invaded Vitex negundo native populations. Sampling was conducted at 60 locations with extensively diverse soil and vegetation characteristics along road, rural and urban areas for comparison in Khyber Pakhtunkhwa, Pakistan. Our results revealed that Xanthium populations are growing in nutrient-deficient soils compared to Vitex. Invaded sites were of low nutrients level compared to non-invaded where phosphorus $(\mathrm{P}<0.001)$ and nitrogen $(\mathrm{P}<0.05)$ varied significantly. Soil textural properties were found to be highly fluctuating with the highest variation in clay particles $(\mathrm{P}<0.001)$. Electrical conductivity $(\mathrm{P}<0.001)$ was detected to be higher in non-invaded sites indicating that these sites are nutrient-rich compared to invaded ones. This fact is further evidenced by the species richness and diversity in invaded sites which were found to be floristically poor compared to the non-invaded sites. We concluded from this study that $X$. strumarium invasion can be successful in nutrient-deficient habitats and can invade the native plant communities with higher frequency because of the ample amount of nutrients available.
\end{abstract}

Keywords: biotic and abiotic factors, low resources environment, poor floristic, native plant communities

\section{Introduction}

Plant invasion has dramatic effects worldwide on biodiversity and materials cycling disturbing many ecosystem services throughout the globe (Rai and Singh, 2020). It is generally believed that invasive species have suitable traits with evolutionary adaptations that enable them to flourish well in a new environment (Rout and Callaway, 2009) thereby altering communities' composition and ecological association with ultimate effects on ecosystem conservation and services (Bartz and Kowarik, 2019). Besides, plant invasion provides key information about the usefulness of plant species in ecosystem development and their economic role (Díaz and Cabido, 2001). Most prominently, the non-native plants disturbed nutrients cycling and soil composition (Wang et al., 2015) by adapting and inheriting certain traits in the new prevailing environmental conditions and thus negatively affecting plant communities and endangering native useful plant species (Milanović et al., 2020).

Successful invasion depends on the environmental resources of a habitat where the plant species can grow and interact with native plants, ultimately leads to its disturbance and destruction (Thompson et al., 2001). It is generally believed that plants usually grow faster and densely populated in nutrient rich habitats with good yield and economic benefits (Gross et al., 2005). Conversely, invasive plants adjust in low resource conditions by the positive feedback mechanism and efficiently utilize the materials promoting disturbance thus making the conditions suitable for their growth temporally (Funk, 2013). 
Limited resources caused many adaptations in plants like the lower concentration of chemicals in tissues making the leaves thick, chemical compounds for defense, and resource use efficiency (Coley et al., 1985; Funk, 2013). Among these, resource use efficiency (RUE) is a key mechanism that enables the invasive plants to get success in a new environment with a high rate of propagation, growth, and development (Reed, 2005). In theoretical and community ecology the concept of limiting similarity theory (LST) has revealed that invasive species differ from native plants in many traits to enable themselves in invading the new harsh environment acquitting their requirements from low resources condition (MacArthur and Levins, 1967; Deng et al., 2004). In this context, several factors have been reported that affect successful invasion i.e., type and frequency of limited resources, the density of individuals, disturbance regime, and traits for resources conservation (Foxcroft et al., 2011). Plants invading environments with low resources completely use a different mechanism from those invading environments with high resources (Craine et al., 2005). Researchers have suggested that plant invading environment with high resources succeeded through resource acquisition while low resource species adapted to resource conservation (Craine, 2009).

Xanthium strumarium L. (hereafter $X$. strumarium) is one of the invading noxious weeds that significantly reduced the yield of different cereals and economically important crops like cotton, maize, soybeans, corns, and groundnuts (Hussain et al., 2014). In Pakistan, this plant has been reported as a predominant weed by Baloch et al. (1968) which was originated from northern Afghanistan through domesticated animals' and refugees' movement with rapid invasion in different parts of Khyber Pakhtunkhwa province during the late 1970s (Hashim and Marwat, 2002). Owing to the invasiveness and invasibility, we conducted this research to elucidate the complex relationships involved in the successful invasion of $X$. strumarium in the recipient ecosystem. Besides many other reasons, this research aimed to address whether this species can successfully invade and adopt in the condition of the low resources in different ecological habitats. We take into account the abiotic environment and vegetation in $X$. strumarium invaded and nearby non-invaded sites dominated by Vitex negundo (hereafter $V$. negundo) populations for the comparison of soil physiochemical properties and nutrients. This research will not only provide baseline information on how this species successfully invaded and occupied the areas with scarce resources in the native vegetation by modifying the soil's physical and chemical characteristics but will also be helpful in better understanding the invasion of other species in the region.

\section{Materials and methods}

\section{Study area}

This study was conducted in Khyber Pakhtunkhwa which is one of the five administrative provinces of Pakistan situated in the north-west region. The province is surrounded by Azad Jammu \& Kashmir (AJK) in the north-east, Afghanistan and FATA in the west, Punjab in the east while Balochistan province lies southward (Khan, 2015). The province is covered with different mountainous ranges on the north-west and eastern part i.e., Himalayan, Hindukush and Karakorum ranges. The elevation of the province varies greatly from plains (327 $\mathrm{m}$ at Peshawar) towards mountains (7708 $\mathrm{m}$ at Tirch Mir) that lies in the Hindukush range (Rahman and Dawood, 2016). The sampling sites cover an elevation ranging from $360 \mathrm{~m}$ to $1200 \mathrm{~m}$ above sea level and are located between 34.59 to $34.85 \mathrm{~N}^{\circ}$ latitudes and 71.44 to $72.82 \mathrm{E}^{\circ}$ longitudes (Fig. 1). 


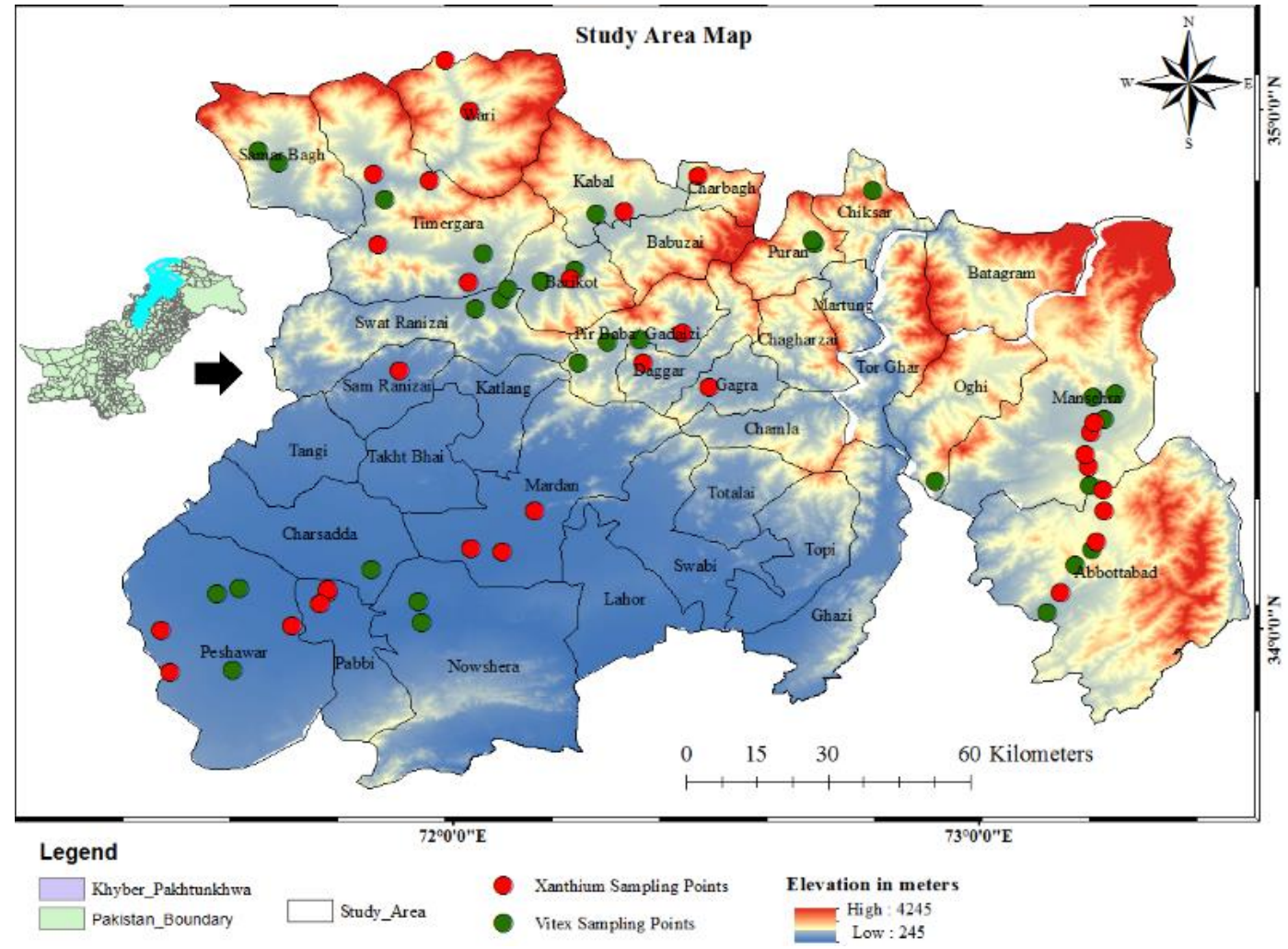

Figure 1. Map of the study area with digital elevation model of Arc GIS while sampling sites of Xanthium are shown in red and that of Vitex in green legends

The environmental protection agency (EPA) has divided the province into four agroecological zones (Table 1), based on the physiographic attributes and climate. The province has characterized by undulating valleys and plains surrounded by high mountains which significantly affect the climate along the elevation gradient from south to north and northwest in the region. Highlands are cold in winter and mild in summer with an obvious rise of temperature towards the South (Ali et al., 2018). June is the hottest month with a mean maximum and minimum temperature of $34.96 \pm 1.36{ }^{\circ} \mathrm{C}$ and $19.10 \pm 1.50{ }^{\circ} \mathrm{C}$, respectively. January is the coldest month with a mean maximum and minimum temperature of $13.72 \pm 1.39{ }^{\circ} \mathrm{C}$ and $0.67 \pm 0.97{ }^{\circ} \mathrm{C}$ indicating that winters are more severe where the temperature generally falls below freezing point (Rahman and Khan, 2013). The average annual precipitation ranges from $384 \mathrm{~mm}$ to $639 \mathrm{~mm}$ whereas the relative humidity varies between $54.81 \pm 2.18 \%$ to $77.35 \pm 3.12 \%$ (Ali et al., 2018) as summarized in Table 2. The climate of the area plays a pivotal role in the economic, social, hydrological, and agricultural activities of the area and thus necessary in vegetation structure analysis (Deo and Sahin, 2015).

Table 1. Showing the agro-ecological zones in Khyber Pakhtunkhwa, Pakistan

\begin{tabular}{c|c|c|c|c}
\hline Zone Name & A & B & C & D \\
\hline \multirow{5}{*}{ Districts } & Northern mountainous & Eastern mountainous & Central plains & Piedmont plains \\
& region (Swat, Dir & region (Torghar, & (Mardan, Swabi, & and Suleiman \\
& Lower and Upper, & Kohistan, Haripur, & Kohat, Nowshera, & (Bannu, Lakki \\
& Shangla, Bunir, & Mansehra, Abbotabd, & Hangu, Karak, & Marwat, Tank, \\
& Chitral) & Battagram & Peshwar, Charsadda) & Dera Ismail Khan) \\
\hline
\end{tabular}


Table 2. Geographic co-ordinates, elevation and climatic conditions of studied sites

\begin{tabular}{cc|cc|cc|cc|cc|cc}
\hline \multicolumn{2}{c|}{$\begin{array}{c}\text { Latitude } \\
\left({ }^{\circ}\right)\end{array}$} & \multicolumn{2}{c|}{$\begin{array}{c}\text { Longitude } \\
\left({ }^{\circ}\right)\end{array}$} & \multicolumn{2}{c|}{$\begin{array}{c}\text { Elevation } \\
(\mathbf{m})\end{array}$} & \multicolumn{2}{c|}{$\begin{array}{c}\text { Temperature } \\
\left({ }^{\circ} \mathbf{C}\right)\end{array}$} & \multicolumn{2}{c|}{$\begin{array}{c}\text { Relative } \\
\text { Humidity }\end{array}$} & \multicolumn{2}{c|}{$\begin{array}{c}\text { Precipitation } \\
(\mathbf{m m})\end{array}$} \\
\hline Min & Max & Min & Max & Min & Max & Min & Max & Min & Max & Min & Max \\
34.59 & 34.85 & 71.44 & 72.82 & 327 & 1200 & 7.19 & 37.03 & 54.81 & 77.35 & 384 & 639 \\
\hline
\end{tabular}

Note: the coldest and warmest months' temperature were taken as mean as well as relative humidity

\section{Studied species}

We studied two different populations for comparison including an exotic invasive (Fig. 2a) and a native species (Fig. 2b) in this research. X. strumarium is a member of the family Asteraceae, which grow as an annual herb (about $150 \mathrm{~cm}$ in height) with a tap root system and usually propagate by seeds (Alex et al., 1980; Venodha, 2016). The morphometric characteristics of the plant show ovate, triangular alternate leaves, hairy stem and racemose inflorescence with pistillate heads below the staminate inflorescence (Love and Dansereau, 1959). Physiologically, it is a short-day plant that approximately requires 7.5 hours for flowering in northern while 10-hours photoperiods in southern areas (Abdulrahman and Winstead, 1977). The fruits (spiny bur) are up to $2 \mathrm{~cm}$ long with two stouts at the end and two achenes (Hicks, 1971) and often grow along shores and cultivated lands (Nadeau, 1961) as weed particularly in soybeans and cotton, thereby enormously reducing (up to 70\%) yield of both crops (McWhorter and Anderson, 1976). Besides, it has also reduced wool production and caused many disorders in livestock due to harmful chemical constituents (Holm et al., 1977). This plant has been introduced from North America to many Asian countries including Pakistan especially in Khyber Pakhtunkhwa province where it spread from plains to higher zones and massively damaged District Nowshera and Abbottabad in the last two decades (Marwat, 2010). X. strumarium is more evident in open patches and along the road-sides and agriculture cropland due to its transport from Afghanistan through sheep's and goats during the Afghan nomad's movement (Hashim and Marwat, 2002) and now it acts as a strong ruderal component in the ecosystem. $V$. negundo commonly known as Marwadai that belongs to family Lamiaceae often grow as a shrub and rarely small deciduous tree with specific aroma (Ilyas, 2015). The plant reaches 3-9 ft in height and distributed in Indo-Malaysia, Asia, West Indies and America (Liu et al., 2005). The plant has a fairly thick brown root (about $8-10 \mathrm{~cm} \mathrm{dbh}$ ) (Vinuchakkaravarthy et al., 2011) and distinct by its palmately compound leaves with 3-5 leaflets. The flowers are usually axillary or terminal panicle and succulent black color ripped fruits are typical with four rounded seeds about $4 \mathrm{~mm}$ in diameter (Meena et al., 2011). Ecologically, this plant grows vigorously on loamy soils and usually preferred wet areas and forest lands (Khare, 2004). Medicinally, it is very important and often used as an analgesic, anti-inflammatory, anthelminthic, and anti-venom while its extracted oil is used as a diuretic and expectorant (Arora et al., 2011). It's has been used to strengthen immunity and frequently used in many Ayurvedic remedies for treating a wide range of diseases (Tiwle and Sanghi, 2015).

\section{Soil sampling and floristic data collection}

Collection of soil samples and vegetation data was carried from May to October 2018. The sampling sites were of two categories i.e., invaded and non-invaded which were further divided into three types i.e., road-sides, urban and rural to understand the intra and 
interspecific changes. The selection for sampling was based on the target species under investigation from sites with least to moderate (non-invaded) and more or entirely (invaded) anthropogenically disturbed often perceived as detrimental to plant biodiversity (Vanderhoeven et al., 2005). Finally, vegetation sampling was performed in 60 different stands (30 each) by using a plot size of $5 \mathrm{~m}^{2}$ along $50 \mathrm{~m}$ transects at various physiographic situations and habitats. Five replicates of soil were collected from each plot at a depth of 10$30 \mathrm{~cm}$ in sites dominated by $X$. strumarium or $V$. negundo vegetation. The replicates were mixed to make a homogenized sample of $500 \mathrm{~g}$ following Elberling et al. (2004). Plant debris and small pebbles were removed from each sample by crushing peds with the grinding machine and were then allowed to air-dry. Each sample was passed through a sieve of 2-mm before physiochemical properties and nutrients analysis. Bouyoucos hydrometer method was used for determining soil texture properties (Day, 1965) and a soil suspension (1:5) was made for the determination of $\mathrm{pH}$ using a $\mathrm{pH}$ meter (Model CON.3173) immediately in the field. Soil organic matter was estimated by oxidation method following Walkley and Black (1934), whereas potassium was estimated in unbuffered NH4OAc of 1 molar (M) concentration (Thomas, 1982) using an Atomic absorption spectrophotometer (VARIAN model-AA2407, USA). Nitrogen was determined by digesting the samples in $\mathrm{H}_{2} \mathrm{SO}_{4}-\mathrm{H}_{2} \mathrm{O}_{2}$ and analyzed with an auto-analyzer whereas, phosphorus was estimated calorimetrically by using $\mathrm{NaHCO}_{3}$ of $0.5 \mathrm{M}$ concentration (Murphy and Riley, 1962; Olsen and Sommers, 1982). Electrical conductivity was determined by using a conductometer (Model CON 5).

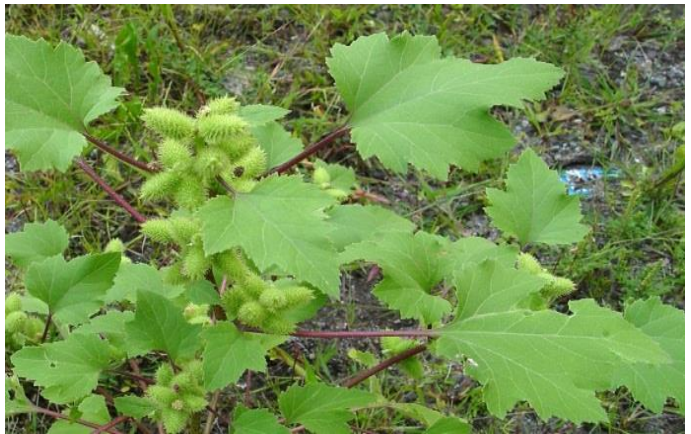

a)

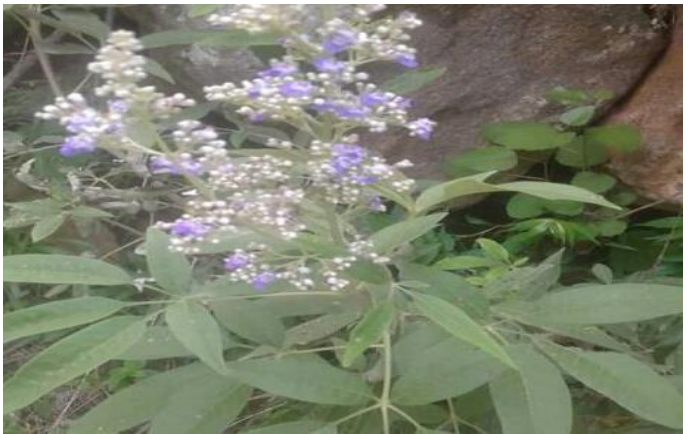

b)

Figure 2. a) Xanthium strumarium L. with pistillate flowers surrounded by a spiny involucre and $\boldsymbol{b})$ Vitex negundo L. with palmate compound leaves and inflorescence having bluish purple color flowers

\section{Statistical analysis}

Phytosociological attributes for individual species were obtained and the importance values index (IVI) were calculated by transforming the relative values i.e., frequency, density, and the cover as IVI $=100 \times\left(\mathrm{F}_{3}+\mathrm{D}_{3}+\mathrm{C}_{3} / 3\right)$ following Mueller-Dumbois and Ellenberg (1974) and Brower et al. (1998). We computed descriptive statistics (Mean $\pm \mathrm{SE}$ ) for soil characteristics and the difference among the sites mean (i.e., urban, rural, and road-sides) were compared by using one-way analysis of variance (ANOVA) following a post hoc Tukey HSD test (Hughes and Uowolo, 2006). Additionally, a paired t-test was performed for the physiochemical and nutrient characteristics to seek any statistical differences between invaded and non-invaded sites. All the statistical analysis was carried out in Microsoft Excel and Graph Pad (ver.8.0). 


\section{Results}

\section{Soil physiochemical properties and nutrients}

Multiple resources in soil were found to be of low concentration in sites invaded by $X$. strumarium compared to $V$. negundo. The variations among soil textural properties and nutrients concentrations were found to be significant between the invaded and non-invaded sites. Site types i.e., roads, urban and rural was also found to play a significant role in the distribution and variation of nutrients in the study areas as shown in Figure 3, respectively. Concerning soil textural properties, clay particles exhibited a significantly strong variation $(F=49.38, d f=5,54, p<0.01)$ among invaded and non-invaded sites. In soil physical characteristics, $\mathrm{pH}$ and electrical conductivity were found to be lower in invaded sites resulting in low resource condition that suggest comparatively higher availability of nutrients in non-invaded sites. The difference in $\mathrm{pH}$ $(F$-value $=11.409, d f=5,54, p<0.05)$ and electrical conductivity was statistically significant $(F$-value $=12.43, d f=5,54, p<0.05)$. Besides, significantly high differences in two important soil nutrients i.e., phosphorus $(F=12.09, d f=5,54, p<0.05)$ and potassium $(F=7.93, d f=5,54, p<0.05)$ were found between invaded and non-invaded sites indicating that invaded sites were of low nutrient concentration followed by organic matter, organic carbon, total carbon and nitrogen $(p<0.05)$. This pattern was consistent among the road, urban, and rural sites respectively indicating that the nutrient level has a significantly lower value in invaded sites than the non-invaded sites. The results demonstrated that $X$. strumarium population has established faster with high efficiency than the $V$. negundo vegetation thereby utilizing and sustaining in the environment with low nutrients. The nutrient concentrations between invaded and noninvaded sites were also compared using a paired t-test which shows a considerably high variance of nutrients in non-invaded sites which generally elucidate an environment with low resources in invaded sites (Fig. 3).

\section{Vegetation associations}

We found 114 plant species belonging to 58 families in both the invaded and noninvaded sampling sites. Native vegetation was found to be species-rich with 92 different species compared to stands dominated by exotic invasive species. The most representative families were Asteraceae (26 spp), Amaranthaceae (10 spp), Moraceae, Lamiaceae (5 spp each), Poaceae, and Papilionaceae (3 spp each). The remaining 9 families were represented by 2 species each whereas 43 of the families were represented by single species. The invaded sites were usually dominated by $X$. strumarium with mean importance values ranging from 42.49 to $47.26 \%$ whereas, the non-invaded sites dominated by $V$. negundo with importance values ranging from $48 \%$ to $55 \%$ (Table 3). The IV values show that exotic species have densely invaded the urban sites where only 2 species were found as co-dominant with IV greater than 5\%. Table 3 shows that Cannabis sativa of the family Cannabaceae was a strong companion (IV= 10.81 to $11.98 \%$ ) with the vegetation in road, rural and urban sampling sites, whereas, Chenopodium album (IV=8.23\%) and Datura innoxia (IV=7.54\%) were prominently associated species along road-sites. Conversely, the vegetation composition of noninvaded sites was different and predominated by $V$. negundo and Justicia adhatoda (9.33 to $23 \%)$ in the road and urban sites followed by Cannabis sativa (IV=13\%) in rural sites vegetation (Table 3). 


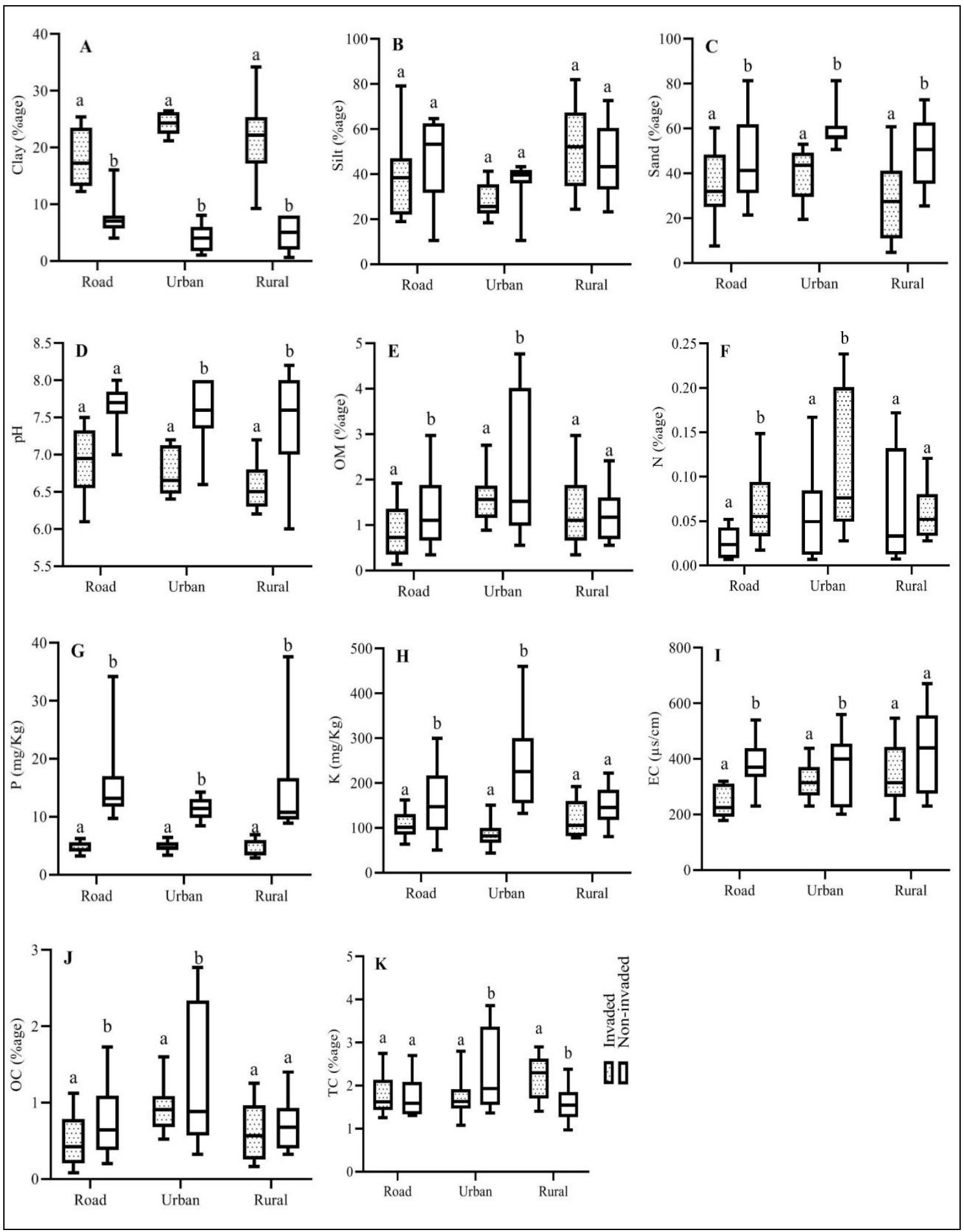

Figure 3. Comparisons among different physiochemical properties of road, urban and rural sampling sites. * Same letters i.e. a: a indicating no significant difference between invaded and non-invaded sites while different letters i.e. a:b indicating significant difference between invaded and non-invaded. (Calculated through paired t-test at $p$ <0.05). A. \%age Clay: B. \%age Silt: C. \%age Sand: D. pH: E. \%age Organic matter: F. Nitrogen \%age: G. Phosphorus (mg/Kg): H. Potassium (mg/Kg): I. Electrical conductivity $(\mu \mathrm{s} / \mathrm{cm}): J . \%$ oge Organic Carbon: K. \%age Total Carbon 
Table 3. Top fifteen dominant plant species in different habitats (road, rural and urban) recorded in invaded and non-invaded sites. Importance Value Index was computed as Mean \pm Standard Error

\begin{tabular}{c|c|c|c|c|c|c}
\hline \multirow{2}{*}{ Plant Name } & \multicolumn{2}{|c|}{ Road } & \multicolumn{2}{c|}{ Rural } & \multicolumn{2}{c}{ Urban } \\
\cline { 2 - 7 } & $\begin{array}{c}\mathrm{M} \pm \mathrm{SE} \\
(\mathrm{In})\end{array}$ & $\begin{array}{c}\mathrm{M} \pm \mathrm{SE} \\
(\mathrm{N})\end{array}$ & $\begin{array}{c}\mathrm{M} \pm \mathrm{SE} \\
(\mathrm{In})\end{array}$ & $\begin{array}{c}\mathrm{M} \pm \mathrm{SE} \\
(\mathrm{N})\end{array}$ & $\begin{array}{c}\mathrm{M} \pm \mathrm{SE} \\
(\mathrm{In})\end{array}$ & $\begin{array}{c}\mathrm{M} \pm \mathrm{SE} \\
(\mathrm{N})\end{array}$ \\
\hline Xanthium strumarium $\mathrm{L}$. & $42.49 \pm 1.46$ & - & $43.44 \pm 1.84$ & - & $47.26 \pm 3.27$ & - \\
Vitex negundo $\mathrm{L}$. & - & $48 \pm 1.47$ & - & $54.5 \pm 1.45$ & - & $55 \pm 2.51$ \\
Cannabis satia $\mathrm{L}$. & $10.81 \pm 1.64$ & $13 \pm 1.23$ & $11.98 \pm 1.54$ & $7.34 \pm 4.67$ & $11.4 \pm 3.04$ & $4.15 \pm 1.88$ \\
Adathoda viscosa $\mathrm{L}$. & - & $23 \pm 2.3$ & - & $1.37 \pm 1.11$ & - & $9.33 \pm 2.17$ \\
Eryngium caeruleum M.Bieb. & - & $6.5 \pm 6.5$ & - & $12 \pm 1.2$ & $4.17 \pm 1.50$ & $4 \pm 1.53$ \\
Datura inoxia L. & $7.54 \pm 1.49$ & - & $4.20 \pm 2.04$ & - & $6.34 \pm 2.85$ & - \\
Chenopodium album L. & $8.23 \pm 0.93$ & - & $4.86 \pm 1.42$ & - & - & - \\
Ailanthus altissima (Mill.) Swingle & - & $5 \pm 2.42$ & - & $2.5 \pm 2.5$ & - & $2.12 \pm 0.93$ \\
Verbascum thapsus L. & - & $3.33 \pm 1.20$ & - & $2.25 \pm 1.93$ & - & $2.12 \pm 0.93$ \\
Amaranthus viridis L. & $3.37 \pm 1.55$ & - & $3.60 \pm 1.10$ & - & $3.71 \pm 1.62$ & - \\
Cynodon dactylon (L.) Pers. & $6.54 \pm 1.46$ & - & - & - & $2.08 \pm 0.89$ & - \\
Carthamus oxycantha Bieb & - & - & $3.64 \pm 1.39$ & - & - & - \\
Silybum marianum (L.) Geartn & - & - & $5.87 \pm 1.95$ & - & - & - \\
Tagetes rectus L. & - & - & - & - & $3.27 \pm 2.44$ & - \\
Daphne mucronata Royle & - & $6.166 \pm 2.12$ & - & $1.75 \pm 1.75$ & - & $0.5 \pm 0.5$ \\
\hline
\end{tabular}

In: Invaded sites, N: Non-invaded sites: -: absence of species in given group: Details of all the plant species are available as supplementary materials in Table Al

\section{Discussions}

Humans are believed to play a key role in the dispersion of invasive plants especially in crossing aquatic barriers after which the exotic species establish, naturalized, and propagate efficiently (Seabloom, 2003). However, discovering the mechanism adopted by the invasive plants for finding ways in a new environment was a challenging task for ecologists for decades (Qureshi and Arshad, 2017). Researchers have reported that invasive species grow in environment with rich resources which brings variations in the invaded areas (Davis et al., 2000; Stohlgren et al., 2008). Our results did not support this concept rather the idea of limiting resources as formulated by Han et al. (2012). In the low resource system, invasive species conserved resources for better development and propagated even in harsh environments as reported by Funk and Vitousek (2007) which provide strength to our findings. The invasive plants have certain traits that enable them to maintain life even in low resources (Funk, 2008) efficiently with a complicated mechanism. X. strumarium an invasive species in northern Pakistan may have one of the possible adaptations reported by Grime (1977) and Funk (2008).

It was argued by Davis et al. (2000) that invasive plants used their traits efficiently according to the needs and requirements in the environment with fluctuating resources and has therefore gained the attention of researchers. It is believed that invasion in environment with low resources has resulted in disturbance and increased resource concentration with time (Antonio et al., 1999) despite the fact that native plants compete strongly with invasive species. Nevertheless, in certain conditions, the invasive plants get success in a new environment with a high growth rate and propagation pressure with a 
less known mechanism (Suding et al., 2004). This efficiency enables the invasive plants to establish well and compete the native plant species in low resource environments (Blumenthal, 2005). These statements proactively support the establishment of $X$. strumarium which propagates well in low resource conditions and will propagate rapidly if invaded the resource-rich environment compared to native plants like V. negundo (Fig. 3).

Identification of characters that enable the plants to occupy low resource conditions is difficult and complex to be realized since plants have a complex internal mechanism that needs to be evaluated (Tecco et al., 2010). However, invasive plants rather used completely different mechanisms from native plants to grow and establish in low resource environments thereby absorbing and conserving resources more efficiently (Wright et al., 2004; Funk and Vitousek, 2007). This behavior of invasive plants poses serious threats to native biodiversity as indicated by Holmes and Cowling (1997). Somewhat similar behavior was also shown by X. strumarium (Table 3), resulting in poor vegetation composition in the invaded sites compared to non-invaded. On the other hand, homogenization of biotic communities is a challenging task for ecologists throughout the globe because it rapidly and unnoticeably decreases the native flora by invasive alien species (Mckinney and Lockwood, 1999). The Present study reveals higher diversity in non-invaded sites compared to the invaded site as non-invaded sites were found to have ninety-two different species while invaded sites have forty-five species only. These findings are supported by studies like that of Qian and Guo (2010), who recorded invaded areas to be less diversified compared to native plant communities in North America. Several other factors that enable invasive species to be naturalized and dominate in an area varies considerably due to efficient dispersal of seeds and fruits, fecundity and fidelity, an adjustment in the prevailing environmental conditions, growth rate and biomass production, etc. (Devin and Beisel, 2007; Gosper and VivianSmith, 2009). These characteristics enable the invasive plants to occupy a variety of habitats with higher distribution in many regions and in some cases become cosmopolitan (Rejmánek and Richardson, 1996).

The key factor in promoting biotic homogenization is plant habits and their lifeforms which contribute to promoting plant communities' disturbance. It was found that biennial and annual plants have more severely homogenized plant communities as compared to perennial plants (Qian and Guo, 2010). In the present study, X. strumarium was usually found to be the strong companion with annual and rarely with biennial plants advocating the findings of Qian and Guo (2010). Contrary to our results, researchers have also reported the homogenization of perennial plants (e.g., Milchunas et al., 1988; Tappeiner et al., 1991). Also, herbs were found with a more pronounced effect on homogenization of plant communities compared to shrubs and trees due to their efficient propagation potential and reproduction compared to other life-forms (Ricklefs et al., 2008). Although, X. strumarium is a shrub it produces a large number of seeds and fruits and is therefore spreading and propagating rapidly compared to $V$. negundo in the region.

\section{Conclusions and limitations}

Invasive plants have great potential to grow and propagate in diverse environmental conditions. X. strumarium an alien invasive species in Khyber Pakhtunkhwa has been established and adapted to a wide range of environmental conditions compared to native plant species. The eradication and control of invasive plants may better be understood 
by understanding the mechanism that favors invasive plant growth and reproduction. Our study focuses on the comparison of soil and vegetation between invaded and noninvaded sites in terms of soil physiochemical and nutrients concentration levels with phytosociological characters of associated plant species. Many other factors may enhance or decrease plant growth of invasive and native plants like climate, atmospheric moisture, light, and others, thus our study has the limitation in considering these factors in plants propagation and growth. This study is also restricted only to plant species with no animal invasion and its associated phenomenon. We further recommended that government departments like agriculture, livestock and forestry, and non-governmental organizations should immediately take steps for the eradication of this invasive plant species to protect the $V$. negundo communities in particular which is an important native medicinal plant and other native plant communities in general for the safety of the crops.

Acknowledgments. The authors sincerely acknowledge the local communities for providing hospitality and accommodation during the field survey. We also thank Dr. Kishwar Ali for their review and comments on the early version of this manuscript. The comments and suggestions of the anonymous reviewers also considerably improved the quality of this manuscript.

Competing Interests. The authors have declared that no competing interests exist.

Data Availability. The authors confirm that all data underlying the findings are fully available without restriction. All relevant data are within the paper along with supporting information files. Raw data can also be provided by the authors on request.

Funding. This study was self-supported by the authors and no funding agency was involved in the study design, data collection, and analysis, decision to publish, or preparation of the manuscript.

\section{REFERENCES}

[1] Abdulrahman, F. S., Winstead, J. E. (1977): Chlorophyll levels and leaf ultrastructure as ecotypic characters in Xanthium strurmarium L. - American Journal of Botany 64: 11771181.

[2] Alex, J. F., Cayouette, R., Mulltgan, G. A. (1980): Common and botanical names of weeds in Canada. - Research Branch, Agriculture Canada, 132p.

[3] Ali, A., Khan, T. A., Ahmad, A. (2018): Analysis of Climate Data of Khyber Pakhtunkhwa, Pakistan. - International Research Journal of Engineering and Technology 5(5): 4266-4283.

[4] Arora, V., Lohar, V., Singhal, S., Bhandari, A. (2011): Vitex negundo A Chinese Chaste Tree. - International Journal of Pharmaceutical Innovations 1(5): 9-20.

[5] Baloch, G. M., Mohyuddin, A. I., Ghani, M. A. (1968): Xanthium strumarium L.-insects and other organisms with it in West Pakistan. - Commonwealth Institute Biol. Control Tech. Bull 10: 103-111.

[6] Bartz, R., Kowarik, I. (2019): Assessing the environmental impacts of invasive alien plants: a review of assessment approaches. - NeoBiota 43: 69-99.

[7] Blumenthal, D. (2005): Interrelated causes of plant invasion. - Science 310(5746): 243244.

[8] Brower, J. E., Zar, J. H., Von Ende, C. N. (1998): Field and laboratory methods for general ecology. - Wm. C. Brown company publisher.

[9] Coley, P. D., Bryant, J. P., Chapin, F. S. (1985): Resource availability and plant antiherbivore defense. - Science 230(4728): 895-899. 
[10] Craine, J. M., Fargione, J., Sugita, S. (2005): Supply pre-emption, not concentration reduction, is the mechanism of competition for nutrients. - New Phytologist 166: 933940.

[11] Craine, J. M. (2009): Resource Strategies of Wild Plants. - Princeton University Press, Princeton.

[12] D’Antonio, C. M., Dudley, T. L., Mack, M. (1999): Disturbance and Biological Invasions: Direct Effects and Feedbacks. - In: Walker, L. R. (ed.) Ecosystems of Disturbed Ground. Elsevier, The Netherlands, pp. 413-452.

[13] Davis, M. A., Grime, J. P., Thompson, K. (2000): Fluctuating resources in plant communities: a general theory of invasibility. - Journal of ecology 88(3): 528-534.

[14] Day, P. R. (1965): Particle fractionation and particle-size analysis. - In: Page, A. L., Miller, R. H., Keeney, D. R. (eds.) Methods of soil analysis, Part 1. American Society of Agronomy, Soil Science Society of America.

[15] Deo, R. C., Şahin, M. (2015): Application of the Artificial Neural Network model for prediction of monthly Standardized Precipitation and Evapotranspiration Index using hydrometeorological parameters and climate indices in eastern Australia. - Atmospheric Research 161: 65-81.

[16] Devin, S., Beisel, J. N. (2007): Biological and ecological characteristics of invasive species: a gammarid study. - Biological Invasions 9: 13-24.

[17] Díaz, S., Cabido, M. (2001): Vive la différence: plant functional diversity matters to ecosystem processes. - Trends in ecology \& evolution 16(11): 646-655.

[18] Elberling, B., Jakobsen, B. H., Berg, P., Søndergaard, J., Sigsgaard, C. (2004): Influence of vegetation, temperature, and water content on soil carbon distribution and mineralization in four High Arctic soils. - Arctic, Antarctic, and Alpine Research 36(4): 528-538.

[19] Foxcroft, L. C., Pickett, S. T. A., Cadenasso, M. L. (2011): Expanding the conceptual frameworks of plant invasion ecology. - Perspectives in Plant Ecology, Evolution and Systematics 13: 89-100.

[20] Funk, J. L., Vitousek, P. M. (2007): Resource-use efficiency and plant invasion in lowresource systems. - Nature 446(7139): 1079. https://doi.org/10.1038/nature 05719.

[21] Funk, J. L. (2008): Differences in plasticity between invasive and native plants from a low resource environment. - Journal of Ecology 96(6): 1162-1173.

[22] Funk, J. L. (2013): The physiology of invasive plants in low-resource environments. Conservation physiology 1(1): 026.

[23] Gosper, C. R., Vivian-Smith, G. (2009): The role of fruit traits of bird-dispersed plants in invasiveness and weed risk assessment. - Diversity and Distributions 15: 1037-1046.

[24] Grime, J. P. (1977): Evidence for the existence of three primary strategies in plants and its relevance to ecological and evolutionary theory. - The American Naturalist 111(982): $1169-1194$.

[25] Gross, K. L., Mittelbach, G. G., Reynolds, H. L. (2005): Grassland invasibility and diversity: responses to nutrients, seed input, and disturbance. - Ecology 86(2): 476-486.

[26] Han, Y., Buckley, Y. M., Firn, J. (2012): An invasive grass shows colonization advantages over native grasses under conditions of low resource availability. - Plant ecology 213(7): 1117-1130.

[27] Hashim, S., Marwat, K. B. (2002): Invasive weeds a threat to the biodiversity: a case study from Abbotabad District, N-W Pakistan. - Pakistan Journal of Weed Sciences and Research 8: 1-12.

[28] Hicks, A. J. (1971): Systematic studies of Xanthium (Compositae: Ambrosieae); the cockleburs of Tazewell County, Illinois. - Unpubl. Ph.D. thesis. University of Illinois. C\&\#39; hampaign- Urbana, Ill. 60.

[29] Holm, L. G., Plunknett, D. L., Pancho, J. V., Herberger, J. P. (1977): The world worst weeds. - East-West Center Book Univ. Press of Hawaii, Honolulu, Hawaii. 609. 
[30] Holmes, P. M., Cowling, R. M. (1997): The effects of invasion by Acacia saligna on the guild structure and regeneration capabilities of South African fynbos shrub lands. Journal of Applied Ecology 34(2): 317-332.

[31] Hughes, R. F., Uowolo, A. (2006): Impacts of Falcataria moluccana invasion on decomposition in Hawaiian lowland wet forests: The importance of stand- level controls. - Ecosystems 9: 977-991.

[32] Hussain, Z., Marwat, K. B., Cardina, J., Khan, I. A. (2014): Xanthium strumarium L. impact on corn yield and yield components. - Turkish journal of agriculture and forestry 38(1): 39-46.

[33] Ilyas, M. (2015): Phytosociological and ethnobotanical appraisal of Kabal valley swat with especial reference to plant biodiversity conservation. - PhD thesis Department of Botany Arid agriculture university Islamabad.

[34] Khan, F. K. (2015): Pakistan geography economy and people, $4^{\text {th }}$ ed. - Oxford University Press, Pakistan.

[35] Khare, C. P. (2004): Encyclopedia of India Medicinal plants. - Spinger Verlange, Berline, Heidelberge, New York, pp. 474-476.

[36] Liu, C., Tseng, A., Yang, S. (2005): Chinese herbal medicine: modern applications of traditional formulas. - Florida, USA: CRC Press.

[37] Love, D., Dansereau, P. (1959): Biosystematic studies on Xanthium: Taxonomic appraisal and ecological status. - Canadian Journal of Botany 37: 193-208.

[38] MacArthur, R., Levins, R. (1967): The limiting similarity, convergence, and divergence of coexisting species. - The American Naturalist 101(921): 377-385.

[39] Marwat, K. B., Hashim, S., Ali, H. (2010): Weed Management: A case study from NorthWest Pakistan. - Pakistan Journal of Botany 42: 341-353.

[40] McKinney, M. L., Lockwood, J. L. (1999): Biotic homogenization: a few winners replacing many losers in the next mass extinction. - Trends in Ecology and Evolution 14: 450-453.

[41] McWhorter, C. G., Anderson, J. M. (1976): Effectiveness of metribuzin applied preemergence for economical control of common cocklebur in soybeans. - Weed Science 24(4): 385-390.

[42] Meena, A. K., Niranjan, U. S., Rao, M. M., Padhi, M. M., Ramesh, B. (2011): A review of the important chemical constituents and medicinal uses of Vitex genus. - Asian Journal of Traditional Medicines 6(2): 54-60.

[43] Milanović, M., Knapp, S., Pyšek, P., Kühn, I. (2020): Trait-environment relationships of plant species at different stages of the introduction process. - NeoBiota 58: 55-74.

[44] Milchunas, D. G., Salsa, O. E., Lauenroth, W. K. (1988): A generalized model of the effects of grazing by large herbivores on grassland community structure. - American Naturalist 132: 87-106.

[45] Mueller-Dombois, D., Ellenberg, H. (1974): Aims and Methods of Vegetation Ecology. John Wiley and Sons, New York, 547.

[46] Murphy, J., Riley, J. P. (1962): A modified single solution method for the determination of phosphate in natural waters. - Analytica Chimica Acta 27: 31-36.

[47] Nadeau, L. H. (1961): Etude Biosystematique sur le genre Xanthium. - Doctoral dissertation, Université de Montréal.

[48] Olsen, S. R., Sommers, L. E. (1982): Phosphorus. - In: Page, A. L., Miller, R. H., Keeney, D. R. (eds.) Methods of soil analysis, Part 2. American Society of Agronomy, Madison, WI.

[49] Qian, H., Guo, Q. (2010): Linking biotic homogenization to habitat type, invasiveness and growth form of naturalized plants in North America. - Diversity and Distributions 16: 119-125.

[50] Qureshi, H., Arshad, M. (2017): Assumptions for successful plant invasion and Pakistan's stance regarding biological pollution. - Advances in Biology \& Earth Sciences 2(2): 143151. 
[51] Rahman, A., Khan, A. N. (2013): Analysis of 2010-flood causes, nature and magnitude in the Khyber Pakhtunkhwa, Pakistan. - Natural Hazards 66(2): 887-904.

[52] Rahman, A., Dawood, M. (2016): Spatio-statistical analysis of temperature fluctuation using Mann-Kendall and Sen's slope approach. - Climate dynamics 48(3): 783-797.

[53] Rai, P. K., Singh, J. S. (2020): Invasive alien plant species: Their impact on environment, ecosystem services and human health. - Ecological Indicators 111: 106020.

[54] Reed, H. E., Seasteadt, T. R., Blair, J. M. (2005): Ecological consequences of C4 grass invasion of a $\mathrm{C} 4$ grassland: a dilemma for management. - Ecological applications 15: 1560-1569.

[55] Rejmánek, M., Richardson, D. M. (1996): What attributes make some plant species more invasive? - Ecology 77: 1655-1661.

[56] Ricklefs, R. E., Guo, Q., Qian, H. (2008): Growth form and distribution of introduced plants in their native and nonnative ranges in Eastern Asia and North America. Diversity and Distributions 14: 381-386.

[57] Rout, M. E., Callaway, R. M. (2009): An invasive plant paradox. - Science 324(5928): 734-735.

[58] Seabloom, E. W., Harpole, W. S., Reichman, O. J., Tilman, D. (2003): Invasion, competitive dominance, and resource use by exotic and native California grassland species. - Proceedings of the National Academy of Sciences 100(23): 13384-13389.

[59] Stohlgren, T. J., Barnett, D. T., Jarnevich, C. S., Flather, C., Kartesz, J. T. (2008): The myth of plant species saturation. - Ecol Lett 11: 313-326.

[60] Suding, K. N., LeJeune, K. D., Seastedt, T. R., (2004): Competitive impacts and responses of an invasive weed: dependencies on nitrogen and phosphorus availability. Oecologia 141(3): 526-535.

[61] Tappeiner, J., Zasada, J., Ryan, P., Newton, M. (1991): Salmonberry clonal and population structure: the basis for a persistent cover. - Ecology 72: 609-618.

[62] Tecco, P. A., Díaz, S., Cabido, M., Urcelay, C. (2010): Functional traits of alien plants across contrasting climatic and land use regimes: do aliens join the locals or try harder than them? - Journal of Ecology 98(1): 17-27.

[63] Thomas, G. W. (1982): Exchangeable cations. - In: Page, A. L., Millar, R. H., Keeney, D. R. (eds.) Methods of soils analysis, Part 1. American Society of Agronomy, Madison, WI, pp. 159-166.

[64] Thompson, K., Hodgson, J. G., Grime, J. P., Burke, M. J. (2001): Plant traits and temporal scale: evidence from a 5-year invasion experiment using native species. Journal of Ecology 89(6): 1054-1060.

[65] Tiwle, R., Sanghi, D. K. (2015): Comprehensive Study of Nirgundi Plant: A Survey Report. - JIPBS 2(2): 125-130.

[66] Vanderhoeven, S., Dassonville, N., Meerts, P. (2005): Increased topsoil mineral nutrient concentrations under exotic invasive plants in Belgium. - Plant Soil 275: 169-179.

[67] Venodha, P. M. (2016): Landscape Degradation and Restoration-A Planning Approach. International Journal of Environmental Science and Development 7(3): 229-233.

[68] Vinuchakkaravarthy, T., Kumaravel, K. P., Ravichandran, S., Velmurugan, D. (2011): Active compound from the leaves of Vitex negundo L. shows anti-inflammatory activity with evidence of inhibition for secretory phospholipase A2 through molecular docking. Bioinformation 7: 199-206.

[69] Walkley, A., Black, A. (1934): An examination of the Degtjareff method for determining soil organic matter and a proposed modification of the chromic acid titration method. Soil Sciences 37: 29-38.

[70] Wang, C., Xiao, H., Liu, J., Wang, L., Du, D. (2015): Insights into ecological effects of invasive plants on soil nitrogen cycles. - American Journal of Plant Sciences 6(01): 34.

[71] Wright, I. J., Reich, P. B., Westoby, M., Ackerly, D. D., Baruch, Z., Bongers, F., Cavender-Bares, J., Chapin, T., Cornelissen, J. H., Diemer, M., Flexas, J. (2004): The worldwide leaf economics spectrum. - Nature 428(6985): 821. 


\section{APPENDIX}

Table A1. Overall species reported in invaded and non-invaded sites during field sampling in X. strumarium and V. negundo communities of Khyber Pakhtunkhwa, Pakistan

\begin{tabular}{|c|c|c|c|c|c|c|}
\hline \multirow{2}{*}{ Plan Binomial } & \multicolumn{2}{|c|}{ Road } & \multicolumn{2}{|c|}{ Rural } & \multicolumn{2}{|c|}{ Urban } \\
\hline & In & $\mathrm{N}$ & In & $\mathrm{N}$ & In & $\mathrm{N}$ \\
\hline Xanthium strumarium $\mathbf{L}$. & $42.49 \pm 1.46$ & - & $43.44 \pm 1.84$ & - & $47.26 \pm 3.27$ & - \\
\hline Vitex negundo $\mathrm{L}$. & - & $48 \pm 1.47$ & - & $54.5 \pm 1.45$ & - & $55 \pm 2.51$ \\
\hline Cannabis sativa $\mathbf{L}$. & $10.81 \pm 1.64$ & $13 \pm 1.23$ & $11.98 \pm 1.54$ & $7.34 \pm 4.67$ & $11.4 \pm 3.04$ & $4.15 \pm 1.88$ \\
\hline Parthenium hysterosporus L. & $0.98 \pm 0.05$ & - & $0.89 \pm 0.18$ & - & $0.61 \pm 0.88$ & - \\
\hline Datura inoxia $\mathbf{L}$. & $7.54 \pm 1.49$ & - & $4.20 \pm 2.04$ & - & $6.34 \pm 2.85$ & - \\
\hline Sonchus asper (L.) Hill & $0.24 \pm 0.17$ & - & $0.83 \pm 0.28$ & - & $0.42 \pm 0.42$ & - \\
\hline Verbascum thapsus $\mathbf{L}$. & - & $3.33 \pm 1.20$ & - & $2.25 \pm 1.93$ & - & $2.12 \pm 0.93$ \\
\hline Erigeron canadensis (L.) Cronq. & $0.55 \pm 0.55$ & $0.45 \pm 0.32$ & $0.65+0.15$ & - & $.75 \pm 00.52$ & - \\
\hline Capsella bursaa pestoris (L.)Medik & - & - & $1.61 \pm 0.78$ & - & - & - \\
\hline Trifolium repens $\mathrm{L}$. & - & $0.54 \pm 0.11$ & - & $0.21 \pm 0.21$ & - & $0.43 \pm 0.11$ \\
\hline $\begin{array}{c}\text { Calotropis procera (Aiton) } \\
\text { W.T.Aiton }\end{array}$ & $0.31 \pm 0.31$ & & - & $0.12 \pm 0.12$ & - & $0.61 \pm 0.40$ \\
\hline Chenopodium album $\mathbf{L}$. & $8.23 \pm 0.93$ & - & $4.86 \pm 1.42$ & - & - & - \\
\hline Amaranthus viridis $\mathbf{L}$. & $3.37 \pm 1.55$ & - & $3.60 \pm 1.10$ & - & $3.71 \pm 1.62$ & - \\
\hline Lipidium sativa $\mathrm{L}$. & $0.73 \pm 0.25$ & - & $0.42 \pm 0.42$ & - & $0.99 \pm 0.38$ & - \\
\hline Persicaria maculosa S.F.Gray & $0.34 \pm 0.31$ & - & $0.30 \pm 0.19$ & & $0.64 \pm .49$ & - \\
\hline Adhatoda viscosa $\mathbf{L}$ & - & $23 \pm 2.3$ & - & $1.37 \pm 1.11$ & - & $9.33 \pm 2.17$ \\
\hline Taraxicum officinale Weber & $0.62 \pm 0.62$ & - & $0.72 \pm 0.34$ & - & $0.45 \pm 0.45$ & $0.47 \pm 0.47$ \\
\hline Brassica campestris L. & $0.42 \pm 0.34$ & - & $0.41 \pm 0.41$ & $0.42 \pm 0.42$ & - & $0.54 \pm .32$ \\
\hline Eclipta alba $\mathrm{L}$. & $0.69 \pm 0.42$ & $0.47 \pm 0.43$ & - & $0.68 \pm 0.68$ & $0.41 \pm 0.41$ & - \\
\hline Alternanthera pungens Kunth & $0.34 \pm 0.34$ & $0.80 \pm 0.32$ & - & $0.72 \pm 0.62$ & - & $0.87 \pm 0.80$ \\
\hline Eryngium coereculum M-Bieb. & - & $6.5 \pm 6.5$ & - & $12 \pm 1.2$ & $4.17 \pm 1.50$ & $4 \pm 1.53$ \\
\hline Amarathus spinosus L. & $0.67 \pm 0.67$ & - & - & - & $0.71 \pm 0.44$ & - \\
\hline Dysphania ambrosioides L. & - & - & & - & $0.88 \pm 0.09$ & - \\
\hline Chrozophora tinctoria (L.) Raf. & $0.71 \pm 0.71$ & - & - & - & $0.43 \pm 0.43$ & - \\
\hline Tribulus terrestris L. & $0.46 \pm 0.42$ & - & $0.49 \pm 0.49$ & $0.64 \pm 0.33$ & - & $0.87 \pm 0.54$ \\
\hline Polygonum aviculare $\mathrm{L}$. & - & - & $0.58 \pm 0.15$ & - & - & - \\
\hline Heliotropium curassavicum L. & $0.26 \pm 0.23$ & - & - & - & - & - \\
\hline Helianthus annus L. & $0.15 \pm 0.15$ & - & $1.10 \pm 0.54$ & - & $0.19 \pm 0.19$ & - \\
\hline Mirabilis jalapa $\mathrm{L}$. & - & $0.5 \pm 0.21$ & $1.19 \pm 0.75$ & - & - & - \\
\hline Centaurea cyanus L. & - & - & - & $0.29 \pm 0.11$ & $1.09 \pm 0.72$ & - \\
\hline Tagetes erectus $\mathbf{L}$. & - & - & - & - & $3.27 \pm 2.44$ & - \\
\hline Carthamus oxycantha Bieb & - & - & $3.64 \pm 1.39$ & - & - & - \\
\hline Cirsium arvense (L.) Scop. & - & - & $0.92 \pm 0.73$ & - & - & $0.94 \pm 0.74$ \\
\hline Urtica dioica $\mathrm{L}$. & $0.85 \pm 0.43$ & - & $0.92 \pm 0.72$ & & $0.09 \pm 0.07$ & $1.09 \pm 0.72$ \\
\hline Oxalis carniculata $\mathrm{L}$. & $0.21 \pm 0.21$ & $0.23 \pm 0.23$ & - & $0.76 \pm 0.76$ & $0.92 \pm 0.72$ & - \\
\hline Zea mays $L$. & - & $0.43 \pm 0.43$ & - & $0.29 \pm 0.29$ & - & - \\
\hline Silybum marianum (L.) Geartn & - & - & $5.87 \pm 1.95$ & - & - & - \\
\hline Cyprus rotundus L. & - & - & $0.82 \pm 0.42$ & - & $0.35 \pm 0.35$ & - \\
\hline $\begin{array}{c}\text { Eichornia cresipes (Mart.) Solma } \\
\text { in DC }\end{array}$ & $0.78 \pm 0.78$ & - & - & - & - & - \\
\hline
\end{tabular}




\begin{tabular}{|c|c|c|c|c|c|c|}
\hline \multirow{2}{*}{ Plan Binomial } & \multicolumn{2}{|c|}{ Road } & \multicolumn{2}{|c|}{ Rural } & \multicolumn{2}{|c|}{ Urban } \\
\hline & In & $\mathrm{N}$ & In & $\mathrm{N}$ & In & $\mathrm{N}$ \\
\hline $\begin{array}{c}\text { Brossentia papyrifera (L.) L'Herit. } \\
\text { ex Vent }\end{array}$ & $1.10 \pm 0.78$ & - & $0.39 \pm 0.39$ & - & - & - \\
\hline Cucurbita pepo $\mathrm{L}$. & $0.45 \pm 0.45$ & $0.22 \pm 0.22$ & - & $0.33 \pm 0.33$ & - & - \\
\hline Solanum nigrum $\mathrm{L}$ & $0.65 \pm 0.45$ & - & $0.41 \pm 0.41$ & $0.42 \pm 0.42$ & - & $0.61 \pm 0.61$ \\
\hline Trianthema portulacastrum $\mathrm{L}$. & - & - & - & $0.56 \pm 0.42$ & - & $0.76 \pm 0.42$ \\
\hline Prosopis julifolia (Sw.) DC. & - & $0.34 \pm 0.34$ & - & - & $0.43 \pm 0.43$ & - \\
\hline Mentha longifolia $\mathrm{L}$. & - & - & - & - & $0.42 \pm 0.42$ & - \\
\hline Acacia nilotica Willd. & - & - & $0.57 \pm 0.57$ & - & $0.29 \pm 0.29$ & - \\
\hline Physalis minima $\mathrm{L}$. & $0.74 \pm 0.49$ & - & - & - & - & $0.34 \pm 0.34$ \\
\hline Cassia occidentalis L. & - & - & - & - & - & $0.29 \pm 0.29$ \\
\hline Achyranthus aspera $\mathrm{L}$. & $0.54 \pm 0.54$ & $0.42 \pm 0.21$ & - & $0.11 \pm 0.11$ & - & - \\
\hline Cynodon dactylon (L.) Pers. & $6.54 \pm 1.46$ & & - & - & $2.08 \pm 0.89$ & - \\
\hline Tagetes minuta $\mathrm{L}$. & $0.78 \pm 0.67$ & $0.64 \pm 0.21$ & - & $0.53 \pm 0.27$ & $0.89 \pm 0.37$ & - \\
\hline Centaurea ibrica $\mathrm{L}$. & - & $1.2 \pm 0.54$ & - & $0.51 \pm 0.37$ & - & $0.64 \pm 0.47$ \\
\hline Cichorium intybus $\mathrm{L}$. & - & $0.5 \pm 0.5$ & - & $0.56 \pm 0.56$ & - & $0.74 \pm 0.74$ \\
\hline $\begin{array}{c}\text { Dicliptera bupleuroides (Nees) C. } \\
\text { B. Clarke. }\end{array}$ & - & $0.76 \pm 0.43$ & - & $0.64 \pm 0.64$ & - & $0.89 \pm 0.89$ \\
\hline Melia azedarach $\mathrm{L}$. & & $1 \pm 1$ & - & $1 \pm 1$ & - & $1 \pm 1$ \\
\hline Olea ferruginea Royle & - & $0.81 \pm 0.42$ & - & $0.98 \pm 0.47$ & - & $0.78 \pm 0.33$ \\
\hline Ailanthus altisima(Mill.) Swingle & - & $5 \pm 2.42$ & - & $2.5 \pm 2.5$ & - & $2.12 \pm 0.93$ \\
\hline Morus alba $\mathrm{L}$. & - & $0.5 \pm 0.5$ & - & $0.5 \pm 0.5$ & - & $0.5 \pm 0.5$ \\
\hline Pentanema visitum $\mathrm{L}$. & - & $0.6 \pm 0.6$ & - & $0.6 \pm 0.6$ & - & $0.6 \pm 0.6$ \\
\hline Dodonaea viscosa Jacq. & - & $1 \pm 0.21$ & - & $0.3 \pm 0.3$ & - & $0.30 \pm 0.30$ \\
\hline Celtis cuascaica $\mathrm{L}$. & - & $0.96 \pm 0.67$ & - & $0.52 \pm 32$ & - & $0.96 \pm 0.67$ \\
\hline Pheonix dacatylifera $\mathrm{L}$. & - & $1 \pm 0.21$ & - & $0.87 \pm 0.32$ & - & $0.56 \pm 0.32$ \\
\hline Plantago lanceolata $\mathrm{L}$. & - & $0.8 \pm 0.8$ & - & $0.8 \pm 0.8$ & - & $0.8 \pm 0.8$ \\
\hline Thlaspi arvenses L. & - & $0.33 \pm 0.33$ & - & $0.33 \pm 0.33$ & - & $0.33 \pm 0.33$ \\
\hline Mytenious roylensis L. & - & $1 \pm 1$ & - & $0.53 \pm 0.53$ & - & $0.31 \pm 0.31$ \\
\hline Oryza sativa $\mathrm{L}$. & - & $1.5 \pm 1.5$ & - & - & - & - \\
\hline Daphne mucronata Royle & - & $\begin{array}{c}6.166 \pm 2.1 \\
2\end{array}$ & - & $1.75 \pm 1.75$ & - & $0.5 \pm 0.5$ \\
\hline Asparagus gracilis $\mathrm{L}$. & - & $0.4 \pm 0.5$ & - & $0.4 \pm 0.5$ & - & $0.4 \pm 0.5$ \\
\hline Zizypus mauritiana Lam & - & $0.25 \pm 0.25$ & - & $0.25 \pm 0.25$ & - & $0.25 \pm 0.25$ \\
\hline $\begin{array}{c}\text { Maytenus wallichiana (Spreng.) } \\
\text { Raju \& Babu in Bull.Bot. Surv.Ind. }\end{array}$ & - & - & - & $0.33 \pm 0.33$ & - & - \\
\hline Periploca aphylla Tourn. ex. L & - & $0.16 \pm 0.16$ & - & $0.16 \pm 0.16$ & - & $0.16 \pm 0.16$ \\
\hline Oenanthe janvanica (Blume) DC. & - & $0.33 \pm 0.33$ & - & - & - & $0.5 \pm 0.32$ \\
\hline $\begin{array}{l}\text { Artimisia scoparia Waldst. \& Kit. } \\
1802 \text { not Maxim. } 1859\end{array}$ & - & $0.5 \pm 0.32$ & - & $0.65 \pm 0.43$ & - & $\begin{array}{lll}- & \text { r }\end{array}$ \\
\hline Len culinaris Medikus & - & - & - & $1 \pm 1$ & - & - \\
\hline Pimpinella diversifolia $\mathrm{L}$. & - & $1 \pm 1$ & - & - & - & - \\
\hline Oenthera rosea L'Hér. ex Aiton & - & $0.16 \pm 0.16$ & - & - & - & $0.16 \pm 0.16$ \\
\hline Stachys parviflora (Benth.) Vved. & - & - & - & $0.4 \pm 0.6$ & - & $0.4 \pm 0.6$ \\
\hline $\begin{array}{l}\text { Micromeria biflora (Buch.-Ham. ex } \\
\text { D. Don) Benth. }\end{array}$ & - & $0.67 \pm 0.67$ & - & - & - & $0.67 \pm 0.67$ \\
\hline Otostegia lambata (Benth.) Boiss. & - & $0.16 \pm 0.16$ & - & - & - & - \\
\hline Zizypus sativa Mill. & - & - & - & $|0.16 \pm 0.16|$ & - & $0.16 \pm 0.16$ \\
\hline
\end{tabular}




\begin{tabular}{|c|c|c|c|c|c|c|}
\hline \multirow{2}{*}{ Plan Binomial } & \multicolumn{2}{|c|}{ Road } & \multicolumn{2}{|c|}{ Rural } & \multicolumn{2}{|c|}{ Urban } \\
\hline & In & $\mathrm{N}$ & In & $\mathrm{N}$ & In & $\mathrm{N}$ \\
\hline $\begin{array}{l}\text { Geramnium ocellatum Camb. in } \\
\text { Jacq. Voy. Ind. }\end{array}$ & - & $0.16 \pm 0.16$ & - & - & - & $0.37 \pm 0.37$ \\
\hline Robinia pseudoacacia $\mathrm{L}$. & - & $0.33 \pm 0.21$ & - & $0.12 \pm 0.12$ & - & - \\
\hline Euphorbia helioscopia L. & - & $0.75 \pm 0.27$ & - & $0.75 \pm 0.14$ & - & $0.75 \pm 0.24$ \\
\hline $\begin{array}{c}\text { Acacia modesta (Wall.) P. J. H. } \\
\text { Hurter }\end{array}$ & - & $0.75 \pm 0.49$ & - & $0.75 \pm 0.49$ & - & - \\
\hline Tagetus minuta $\mathrm{L}$. & - & $0.37 \pm 0.26$ & - & - & - & - \\
\hline Zanthoxylum armatum DC. & - & - & - & $1.33 \pm 0.56$ & - & - \\
\hline Morus nigra $\mathrm{L}$. & - & $0.33 \pm 0.33$ & - & $0.33 \pm 0.33$ & - & - \\
\hline Berberis vulgaris L. & - & - & - & $0.83 \pm 0.83$ & - & - \\
\hline Asphodelus tenuioflius Cav. & - & $0.83 \pm 0.83$ & - & - & - & - \\
\hline Rubus fruicosus L. & - & $0.33 \pm 0.33$ & - & $0.33 \pm 0.33$ & - & - \\
\hline Ricinus communis $L$. & - & $0.33 \pm 0.33$ & - & - & - & $0.33 \pm 0.33$ \\
\hline Boerhavia procumbent $\mathrm{L}$. & - & $0.6 \pm 0.6$ & - & $0.6 \pm 0.6$ & - & - \\
\hline $\begin{array}{c}\text { Monotheca buxifolia (Falc.) A. } \\
\text { DC. }\end{array}$ & - & - & - & $1.25 \pm 1.25$ & - & - \\
\hline Portulaca quadrifida $\mathrm{L}$. & - & - & - & $0.5 \pm 0.5$ & - & - \\
\hline Morus lavegata L. & - & $0.2 \pm 0.2$ & - & $1.5 \pm 0.5$ & - & - \\
\hline Verbina officinalis L. & - & $0.25 \pm 0.25$ & - & - & - & $0.61 \pm 0.61$ \\
\hline Amaranthus caudatus $\mathrm{L}$. & - & - & - & $1.25 \pm 1.25$ & - & - \\
\hline Marrubium vulgare $\mathrm{L}$. & - & - & - & $0.5 \pm 0.5$ & - & - \\
\hline Galinosega perviflora Cav. & - & $0.75 \pm 0.75$ & - & - & - & $0.75 \pm 0.32$ \\
\hline Limium album $\mathrm{L}$. & - & - & - & $0.25 \pm 0.25$ & - & $0.25 \pm 0.25$ \\
\hline $\begin{array}{l}\text { Chenopodium ambrosoides (L.) } \\
\text { Mosyakin \& Clemants }\end{array}$ & - & $0.5 \pm 0.5$ & - & - & - & $0.5 \pm 0.5$ \\
\hline Ajuga bracteosa Wall. ex. Benth. & - & $0.5 \pm 0.5$ & - & $0.6 \pm 0.6$ & - & - \\
\hline Carthmus lanatus L. & - & $0.33 \pm 0.33$ & - & - & - & $0.34 \pm 0.12$ \\
\hline Avena sativa $\mathrm{L}$. & - & $1 \pm 1$ & - & - & - & - \\
\hline Ficus palmata Forsskål & - & $1.4 \pm 0.34$ & - & - & - & - \\
\hline Euclaptus lanceolata Andrews & - & $1 \pm 0.45$ & - & - & - & $0.8 \pm 0.52$ \\
\hline Medicago sativa $\mathrm{L}$. & - & $0.8 \pm 0.48$ & - & - & - & $0.65 \pm 0.23$ \\
\hline Cassia fistula $\mathrm{L}$. & - & - & - & $0.4 \pm 0.4$ & - & - \\
\hline Cactus dillenii (Haw.) Haw. & - & $0.2 \pm 0.2$ & - & - & - & $0.2 \pm 0.2$ \\
\hline Euphorbia hirta $\mathrm{L}$. & - & $0.4 \pm 0.4$ & - & - & - & - \\
\hline Poplus nigra $\mathrm{L}$. & - & - & - & $0.2 \pm 0.2$ & - & $0.2 \pm 0.2$ \\
\hline $\begin{array}{c}\text { Rabdosia rugosa (Wall. ex Benth.) } \\
\text { H.Hara }\end{array}$ & - & $1.2 \pm 1.2$ & - & - & - & - \\
\hline Zizyphus jujuba Mill. & - & $0.2 \pm 0.2$ & - & - & - & $0.2 \pm 0.2$ \\
\hline Allium cepa $\mathrm{L}$. & - & $0.2 \pm 0.2$ & - & $0.2 \pm 0.2$ & - & $0.2 \pm 0.2$ \\
\hline
\end{tabular}

